\title{
Finitude and Violence: Žižek versus Derrida on Politics
}

John McSweeney

\begin{abstract}
In a recent article, Martin McQuillan has inaugurated a vigorous Derridean critique of a "violent tone" that has recently arisen in continental philosophy, exemplified by Slavoj Žižek's attempt to retrieve Robespierre's notion of “Terror. This article sets out to complicate such critique, opening a new perspective on the DerridaŽižek debate on the question of politics. In particular, it examines Derrida's and Žižek's respective approaches to difference and violence as differing responses to a shared problematic of constructing a consistent (immanent) politics within the horizon of a finite world. It proceeds by elaborating Žižek's critique of Derridean deconstruction, highlighting how Derrida's attempt to minimise violence via maximal openness to difference, within the horizon of the future-to-come, inadvertently reinscribes a minimal but problematic ontotheological trace which ironically circumscribes deconstructive openness to difference. The article goes on to examine how Žižek's alternative construal of a purified violence and (Hegelian) self-difference ends up repeating in somewhat different terms these same problematic features of Derrida's writings. The article concludes by arguing that each approach requires a theoretically-integrated ethos of 'becoming other' in which the unavoidable theoretical anticipation of difference (and the risk of invocation of the ontotheological) is ruptured by the actual encounter with difference.
\end{abstract}

Key words: Derrida, Žižek, finite world, violence

\section{Introduction}

$\mathrm{I}$ $\mathrm{n}$ a recent article, Martin McQuillan inaugurates a vigorous Derridean critique of what he terms a "violent tone" that has lately arisen in contemporary philosophy, exemplified by Slavoj Žižek's attempt to reclaim Robespierre's revolutionary "Terror" for emancipatory politics, and reflected in a broader trend toward what he variously describes as a "new Political Theology," "Theological-Maoism," or "onto-thanato-theology."1 Specifically contrasting Žižek's analysis in "Robespierre, or the 'divine violence' of the

${ }^{1}$ Martin McQuillan, "Extra time and the Death Penalties: On a Newly Arisen Violent Tone in Philosophy," in Derrida Today, 2:2 (2009), 135, 144, 149. 
Terror,"2 with Derrida's scrupulous deconstruction of Kant on the question of the death penalty, McQuillan uncompromisingly exposes what he sees as the gross dangers in the former's Lacanian conception of a political act, which, as an act upon the Real, cannot be justified within the prevailing Symbolic order, but retrospectively generates the conditions of its own legitimacy in transforming the socio-political world. Not least, he contends that such a conception of political act problematically involves "a transcendental affirmation of a non-position of pure negation," which can dismiss any actually available political positions as "mere defence of bourgeois biopolitics."3 One cannot negotiate with its "inhuman madness," because it does not exist within the world, but occupies a position of "strict and pure terror," which depends upon an implausibly absolute distinction between inside and outside, between personal interests and the would-be virtue of a truly revolutionary act. Against what he considers the dangerous violence of such a project, McQuillan suggests the preferability of Derrida's "reassuringly liberal" and "even familiar and banal" politics, which is "against the death sentence, for international law and against the invasion of Iraq...critical of the state of Israel but condemns those who would see it destroyed," and so on. ${ }^{5}$

If McQuillan's criticisms strike at significant dangers associated with Žižek's thought (and with the broader materialist theology of post-Lacanian leftist politics) - and I think that they do - arguably, they also leave out of the equation dimensions of Žižek's framing of this act, which mitigate the charges against him. Indeed, McQuillan's deliberately narrow focus upon Žižek's violent tone inadvertently obscures, I wish to argue, a deeper proximity between Žižek and Derrida than suggested by the article's sharp contrast of their respective politics. ${ }^{6}$ In a provocative vein, it might even be claimed that Žižek's difficulties lie in his remaining too Derridean in his tendency to privilege a decisive 'big-Act-to-come.' However, it will be more precise to say that both thinkers run up against the same limit of finitude upon thinking difference, if from opposite standpoints. (Derrida's strategy is to minimize violence, Žižek's to purify it.) Moreover, Žižek has had good reason to suspect a minimal but problematic theological trace operative in Derrida's messianic response to this limit, even if there are also good reasons to conclude that he has not succeeded in eliminating this trace from his own work. To do justice to Žižek and to the debate which needs to be had between Derrida and Žižek on

2 Slavoj Žižek, "Robespierre, or, The 'Divine Violence' of Terror," in Maximilien Robespierre, Virtue and Terror, ed. by Jean Ducange, trans. by John Howe (New York and London: Verso, 2007), vii-xxxix.

${ }^{3}$ McQuillan, op. cit., 144. Terror," xviii.

4 Žižek's own expression. See Žižek, "Robespierre, or, The 'Divine Violence' of

${ }^{5}$ McQuillan, op. cit., 133, 144.

${ }^{6}$ McQuillan, op. cit., 136. McQuillan makes clear that he is concerned only with the 'violent tone' that he detects in Žižek's work and not with the expanded body of his writings. Indeed, he suggests that, in other contexts, he might well have much to say about Žižek or even find himself defending him. I wish to suggest, however, that it is only in locating Žižek's 'violent tone' within the larger framework of his writings that its precise force can be understood. 
the question of politics - a debate which McQuillan importantly inaugurates ${ }^{7}$ it is necessary to recognize that, whatever the dangers of his own solution, Žižek's project is shaped by sensitivity to what he takes to be the violence in Derrida's 'liberal' attempt to minimize violence. Moreover, his work is driven by a concern to articulate an alternative political economy of finite, immanent difference and, indeed, of violence. In what follows, the aim is to make a contribution to the Derrida-Žižek debate by identifying the common 'problematisation' of finite difference which underpins each thinker's approach, with a view to grasping the stakes and dangers of their respective solutions.

\section{Žižek's Criticism of Derrida}

Žižek's fundamental criticism of Derrida's messianic ethics of difference, given succinct expression in The Puppet and the Dwarf, is that it tends to reduce difference to a "pure potentiality" to come; that is, contemporary difference is subordinated to a possibility of a decisive future difference - in which the apparent impossibility of justice today is overcome. ${ }^{8}$ As is wellknown, such criticism is motivated by concern about the contemporary 'postmodern' tendency to equivocate over the significance of present differences and thus to defer decisive political action. ${ }^{9}$ No less, it is concerned with the danger that Derridean difference-to-come (more precisely difference open to the absolute horizon of the future-to-come) is so abstracted that it is all too readily assimilated to capital's process of abstraction of future commodity value. ${ }^{10}$ From a Derridean perspective, this might well seem like one more simplistic reading, which fails to recognize that, for Derrida, openness to the absolute future as horizon of possibility, beyond the limits of contemporary impossibilities, is the very condition of acting in the present, that openness to the future-to-come is precisely a means of not deferring action, but of delimiting an ethics of difference, so as to act even as one respects the

7 I should note that my focus is less upon McQuillan's specific analysis and range of concerns as such than upon the questions, which his article raises, about Žižek and his relation to Derrida.

8 Slavoj Žižek, The Puppet and the Dwarf: The Perverse Core of Christianity (Cambridge, Massachusetts, and London: MIT Press, 2003), 140. In what follows, I expand, and expand upon, Žižek's rather compressed criticism of Derrida in The Puppet and the Dwarf. By reconstructing the argument in slightly different terms and sometimes with a slightly different emphasis than Žižek's, I seek the better to draw out its implications in more typically Derridean terms and to create a certain distance between Žižek's criticisms and his own alternative conception of difference, through which to problematise the 'self-difference' of Žižek's own work and thus to assess his proposals concerning the conception of difference as self-difference.

9 See, for example, Žižek, "The Real of Sexual Difference" in Interrogating the Real, ed. by Rex Butler and Scott Stephens (New York and London: Continuum, 2005), 314-5.

10 Žižek's concern, in Deleuzian terms, is that deconstruction can all too readily be coopted to capitalist deterritorialization. This theme runs through the whole of Žižek's work. For example, see Žižek, "The Real of Sexual Difference", 314; also, the comments on deterritorialization in Žižek, "Lenin's Full Subjective Engagement," < http://www.lacan.com/ thesymptom/?page id=1012>, 19 August 2011. 
complexities and ambiguities of one's situation. Žižek's criticism, however, is precisely of this nuanced Derridean ethical stance.

For Žižek, Derrida's post-Kantian stress on "the irreducible excess in the ideal concept, which cannot be reduced to the dialectic between the ideal and its actualization," subverts his ethical, justice-oriented intention of remaining open to difference - specifically, that openness to the future to come, limits Derrida's capacity to attend to the actual occurring differences in the present. ${ }^{11}$ Crucial, in this respect, is Žižek's distinction between Derrida's early conception of differance and his later notion of messianicity. Žižek's point is that, although Derrida's early concept of differance already depends upon the distinction between concept/representation and reality, this kind of difference is, in fact, immanently operative in highly significant ways in the texts which Derrida examines. ${ }^{12}$ Hence, Žižek can grant that early Derrida's analysis of difference in terms of differance is adequate to the concrete "self-difference" of the reality (i.e. the texts) under examination. However, when specific instances of difference give way to a formalized notion of 'pure difference to come' Derrida's work, he argues, is no longer attentive to "the pure gap which separates an entity from itself." 13 Żižek's point is given weight by a consideration of the tensions that arise as deconstruction increasingly functions, for Derrida, as a more or less universalizable practice, via the series of its "nonsynonymous substitutions," 14 which allow it to be found anew, immanently operative in new (con)texts.

First, there is a danger of prioritizing analysis of differance and its '(non)synonyms' even when other forms of difference are those most crucial to a given object of study. Implicit here is the notion that continuities between differance and its '(non)synonyms' tend to dominate in Derrida's evolving analyses over the uncovering of unanticipated forms of difference, discontinuous with deconstruction, as new contexts are broached. ${ }^{15}$ Second, and perhaps even more problematically, as deconstruction deconstructs, it loses the consistency and ethical significance that it gains from being a critique of a dominant tradition. Its very capacity to critique effectively a specific modality of a tradition's dominance (logocentrism) and to open new spaces of thought in relation to it gives a specific density to deconstructive practice and justifies it. As it takes centre stage, however; as it begins to appear a more fundamental perspective upon reality than that which it critiques, questions necessarily emerge about the deconstruction of deconstruction itself. It is not that every deconstruction, as a linguistic act realized within the logocentrism that it would critique, remains at a remove from, and thus inadequate to, the

11 Žižek, The Puppet and the Dwarf, 140.

${ }^{12}$ Ibid.

13 Ibid., 141.

14 Jacques Derrida, "Différance," in Margins of Philosophy, trans. by Alan Bass (Harvester Press: Brighton, 1982), 12. These nonsynonymous substitutions include différance, dissemination, negation, messianicity, machinicity, animality)

15 Arguably, this tendency is already indicated by the tension in the term "nonsynonymous substitutions" itself. 
deconstruction operative in texts. This 'gap' is already incorporated within the movement of Derridean deconstruction. Rather, the question of the deconstruction of deconstruction primarily centers upon the deconstructive tendency to conceive of this gap as inscribing the 'self-difference' of things as such, or of inscribing the most significant 'self-difference' of things. ${ }^{16} \mathrm{It}$ is thus a question of how this mapping ${ }^{17}$ obscures the possibility of significant context-immanent differences, which differ decisively from the deconstructive conception of difference - hence, ironically reinscribing, in a somewhat different register, a trace of logocentrism's obscuration of textual différance.

It might well be argued, of course, that deconstruction does not exclude others' pursuit of other forms of critique attentive to other forms of difference; that deconstruction is a specific kind of critique, with its own proper focus and concerns. The implication of Žižek's criticism, however, is that insofar as this delimitation of deconstruction is not exercised within deconstruction itself as a moment of its deconstructive impulse; insofar as deconstruction does not incorporate an openness to that which is other than it - within it and rupturing its practice, demanding that it become other than itself, paradoxically as the practice of deconstruction, in the mode of the deconstruction of deconstruction beyond an economy of 'substitutions' then, it makes a practical claim to generality, that is no less problematic for being practical.

And, indeed, rather than defend deconstruction by pursuing a radical critique of its limits, which would underscore its specificity and thus its specific force, Derrida (Žižek highlights) has rather pursued the opposite strategy of protecting deconstruction from its own logic in order to preserve and extend its significance:

....as Derrida himself has realized in the last two decades, the more radical a deconstruction is, the more it has to rely on its inherent undeconstructible condition of deconstruction, the messianic promise of Justice. This promise is the true Derridean object of belief and Derrida's ultimate ethical axiom is that this belief is irreducible, 'undeconstructible. ${ }^{18}$

For Žižek, then, this "belief" is not the minimal belief in the possibility of justice necessary to any ethico-philosophical enterprise, as Derrida would have it. ${ }^{19}$ Rather, he can cogently argue that it is rooted in, and a consequence

16 Žižek, The Puppet and the Dwarf, 141: "Derrida acts as if the choice is between positive onto-ethics, the gesture of transcending the existing order toward another higher positive Order, and the pure promise of spectral Otherness."

${ }^{17}$ In its anticipatory integration of that which exceeds deconstruction.

18 Ibid., 139.

${ }_{19}$ Jacques Derrida, "Faith and Knowledge: The Two Sources of 'Religion' at the Limits of Reason Alone", in Jacques Derrida and Gianni Vattimo, eds., Religion, trans. by David Webb (Cambridge: Polity Press, 1998), 17-19. 
of, Derrida's attempt to extend differrance and its 'nonsynonyms' to serve as the decisive form of difference operative in any (con)text. Moreover, this appeal to the undeconstructible condition of deconstruction requires a subtle delimitation in advance of what counts as ethically and politically significant difference - a problem that can be seen to follow from the logic of "messianicity without messianism" itself.

Messianicity without messianism refuses any positive notion of being, toward which difference points or moves. However, it maintains that the minimal condition of ethics is that justice - apparently impossible today - is, in principle, possible. The absolute "future-to-come" is the horizon of possibility of a justice-to-come and those acts are ethical that maximally maintain openness to this horizon of possibility: a structure of messianicity without content. ${ }^{20} \mathrm{By}$ attending to différance and its (non)synonyms, by accentuating them, deconstruction aims precisely at such an openness and thus achieves ethicality. Žižek argues, however, that no less than in the case of Sartre - who jettisoned the content of the bourgeois subject, but maintained its form (the fundamentally individual, self-creating subject) - this distinction between the content of messianism and its form (messianicity) is problematic; that the form itself imposes a positive stricture upon difference, which amounts to a minimal but positive (ontotheological) claim about the nature of difference. ${ }^{21}$ The problem is that within a finite world, not (necessarily) shaped by any ontotheology, or a concomitant teleological messianism, there can be no guarantee that attending to difference so as to remain open to the "future-tocome" does justice, or the least injustice, to present difference. For instance, there may simply not be a justice-to-come that justifies such a claim. As Michel Foucault put it in his 1971 debate with Noam Chomsky, the term justice may well be a correlate of the ideological system, which produces injustice, and that any overcoming of injustice would involve transcendence of the notion of justice as well.22 Alternatively, it might be argued that there are only the specific, imperfect and, perhaps, (at least partially) mutually exclusive 'justices' that can be achieved in relation to specific differences within the present. This possibility would not necessarily render the ethical pursuit of justice meaningless, but would locate it within the to-be-probed limits of a finite horizon of historical meanings.

Now, of course, Derrida acknowledges that he cannot know that the promise of the justice-to-come will in fact be realized:

The messianic exposes itself to the absolute surprise and, even if it always takes the phenomenal form of peace or of justice, it ought, exposing itself so abstractly, be

20 Derrida, Specters of Marx: The State of the Debt, the Work of Mourning, and the New International, trans. by Peggy Kamuf (New York and London: Routledge, 1994), xix, 28,55.

21 Žižek, The Puppet and the Dwarf, 140.

22 Michel Foucault and Noam Chomsky, "Human Nature: Justice vs. Power (1971): A Debate between Noam Chomsky and Michel Foucault," in The Chomsky-Foucault Debate: On Human Nature (New York: New Press, 2006), 47-50. 
prepared (waiting without awaiting itself) for the best as for the worst, the one never coming without opening the possibility of the other. At issue here is a 'general structure of experience.'23

The crucial point, however, in relation to Žižek's criticism, is that Derrida's hesitation about the prospects of justice does not qualify the form of his practice, only the degree of certainty with which he knows that his acts are ethical. Hence, Derrida's hesitant hope in the promise of a justice-to-come effectively involves, (again) in practice - insofar as he persists in this specific hope - a minimal, but problematically positive claim about difference: that acting so as to remain open to a future horizon of possibility substantially and adequately engages the specific, concrete differences of any given context. Derrida's explicit appeal to a "general structure of experience" is critical here. It raises the objection: if looking to the 'openness' of this structure leaves one vulnerable not only to the possibility of justice but to "the worst" - and there is nothing to suggest that the former possibility is greater than the latter, Derrida must insist, if he is to avoid invocation of a "positive onto-ethics" 24 then, why look to this openness as the privileged locus of a possible justice? Derrida's appeal to a general structure of experience tends to foreclose this question, by suggesting that this general structure is the matrix of our experience and thus of any possible justice. That is, Derrida makes an implicit claim that this general structure of experience is of general (i.e. decisive) significance for the content of experience as such and for the possible experience of justice in particular - a claim, which mirrors that concerning the putative general significance for critique of deconstruction and its 'nonsynonyms.' And the correlate of this claim to general significance is a privileging of a certain kind of difference - the difference most open to the future-to-come - in spite of the acknowledged radical ambiguities (for justice) of this difference as it is generated by Derrida's 'general structure of experience' open to 'the worst' no less than to justice. ${ }^{25}$

Messianicity thus depends upon a claim about the significance of a general structure of experience and a concomitant privileging of certain forms of difference, whose ambiguities can be embraced only on the basis of this

${ }^{23}$ Derrida, "Faith and Knowledge", 17-18.

24 Žižek, The Puppet and the Dwarf, 141.

25 One might well accept with Derrida that all (con)texts are conditioned by the differings, deferrings and slippages of différance or its 'nonsynonymous substitutions', without thereby accepting his further position that these constitute the decisive differences within that (con)text. This was a concern of Foucault's, in The Archaeology of Knowledge, when he sought to delineate an "enunciative analysis" that "does not mark the line that encloses the domain [of language and linguistic analysis]," but is "deployed in another direction, which intersects them." Without naming him, Foucault is clearly concerned to counter what he considers to be the tendency of Derrida's work to inhibit other forms of critique, by generating a "transcendental obstacle," via the latter's notion that, because it cannot be overcome, the quasi-transcendental limit of language ought to be the primary object of critical discourse. Foucault, The Archaeology of Knowledge, trans. by Alan Sheridan Smith (London: Routledge, 1972), 113. 
claim. However, precisely such claims would appear to be problematic from a position of immanence within a finite world. Certainly, if there is to be an ethics and a possibility of justice, some differences must bear a greater ethicopolitical significance than others. Otherwise, all acts upon difference would have an ethical and political equivalence. However, Derrida's further general claims concerning experience and his claim that one can define a quasi-formal condition, which anticipates (formally, negatively) which differences are significant, would appear to exceed the limits of immanence. And thus his claim would involve a subtle onto-theological assumption and a trace of messianism, about the relation of difference and justice.

The problem can be clarified by reference to Quentin Meillassoux's framing of the problem of contemporary thought in After Finitude. ${ }^{26}$ Meillassoux, in that work, is concerned with the possibility of breaking out of what he takes to be the subjectivism of post-Kantian correlationism - the notion that knowledge of the world is always correlated to a knowing subject; that it is not knowledge of the world 'in-itself but 'for-us'. He wishes to do so, however, without re-invoking an absolutist (or ontotheological) horizon of thought. A crux of an early stage of his argument is the manner in which the correlationist undermines the claims of dogmatists, who would resurrect an absolute principle of knowledge beyond the knowing subject, and the claims of subjective idealists, who would make the correlation itself absolute, effectively asserting that the 'in-itself is identical with the 'for-us'. In each case, Meillassoux argues, the correlationist must proceed by asserting that the factical structures of our world could be wholly other than supposed by the dogmatist or subjective idealist. We are simply ignorant of them. Meillassoux's proposal is that, in so doing, the correlationist implicitly makes a positive claim: the condition of possibility of his denials is that factical reality has the capacity to be wholly other and that this is independent of thinking this claim. It is this capacity to be wholly other which gives Meillassoux an absolute beyond correlationism that avoids the ontotheological absolutism of either the dogmatist or the idealist. ${ }^{27}$

Derrida is not concerned with the possibility of finding an absolute as is Meillassoux. However, his problematic is not entirely dissimilar. In Meillassoux's terms, he asks how it is possible to break out of the subjectivism of post-Kantian thought, without revoking its critique of metaphysics; that is to say, how it is possible to conceptualize difference that is not merely a subjectively preferred difference, but effects justice or at least keeps open the possibility of justice. Moreover, arguably, there is a problem with Meillassoux's line of reasoning, and to this extent, his work inadvertently points to the ontotheological temptation that threatens every immanent post-Kantian discourse. The weak point in Meillassoux's argument concerns his claim that the ignorance appealed to by the correlationist presupposes the positive trans-

${ }^{26}$ Quentin Meillassoux, After Finitude, trans. by R. Brassier (New York and London: Continuum, 2009)

${ }^{27}$ Ibid., $28 \mathrm{ff}$. 
subjective principle that things have the capacity to be wholly other. For Meillassoux, it is only because things have this capacity, independently of thought, that the correlationist can make an argument from ignorance. The counterpoint to this argument, however, is that the correlationist cannot step outside the specific relation between his subjective thinking and the content of this thought: if knowledge of the world is always subjective, equally, his/her subjective thought is immanent to the specific content which he/she is thinking. As such, the correlationist can only appeal to ignorance in specific instances, without being able to generalize from these specific instances. Such generalization, as would permit formulation of Meillassoux's positive principle, would require positing a subjective position outside of the correlation to establish a principle true beyond any of its instances. Such a problematic move can be avoided only if this generalization is construed as a further specific instance of thinking, subject to the same ignorance about its more general truth - a specific correlation whose content would be a principle in relation to specific instances of thought, but not capable of being generalized to all possible cases. While the correlationist might posit the positive principle of objects' capacity to be wholly other, he cannot know that this principle holds beyond his current thinking of it in relation to a delimited number of specific instances.

In this framework, the challenge for Derrida's resolutely post-Kantian discourse, as for the correlationist, is that his thinking of difference must be specific and immanent to the specificity of his successive analyses. The attempt to generalize from the specific 'nonsynonymous' negations of each act of deconstruction, to a 'principle' that governs the movement of ethicallyeffective difference as such, reinscribes a metaphysically problematic horizon of thought, even if Derrida's 'principle' appears negative and minimal. Or rather, Derrida can consistently posit such a principle only if it is immanent to a specific thinking of difference. As such, paradoxically, such a principle is valid within the horizon of the specific instance of thinking - whether a specific historical or political situation, or a specific abstraction from a range of such situations. And to retain this validity, it must remain subject to transformation in relation to the possible 'otherness' of further actual instances of difference. A case might be made that all of Derrida's readings follow this principle: that his '(non)synonyms' are irreducible to one another; in particular, that messianicity is not a general theory, but belongs to a certain moment in his thought. However, there is arguably a greater continuity to his approach, and, even if the notion of messianicity without messianism arises as a specific proposal at a specific moment, it or some form of it - as Žižek highlights - is necessary to maintaining the ethical coherence of deconstruction as such. And indeed, this analysis remains a key part of Derrida's work from its formulation in the mid-1990s through to his death in 2004.28 Thus, in view of the

28 See, for example, Derrida, "For a Justice to Come: Interview with Jacques Derrida (by Lieven de Cauter, 2004)," in The Derrida-Habermas Reader, ed. by Lasse Thomassen (Edinburgh: Edinburgh University Press, 2006), 259-269. 
continuities in difference Derrida's thought uncovers, his notion of messianicity without messianism tends to exceed the limits of the post-Kantian correlation. $^{29}$

In sum, then, if Derrida laudably sets out to minimize the violence of act by acting so as to remain maximally open to difference, ${ }^{30}$ the price of this strategy is, ironically, to close off openness to other forms of difference and the politics that might be associated with them. Indeed, his messianicity tends to close off precisely those forms of difference that exceed any quasi-formal anticipatory 'principle': difference that in its 'pure,' irreducible difference ruptures any such principle in unexpected ways; difference that most fully would generate the "absolute surprise" to which messianicity ought to expose itself. Transposed to the level of politics, this foreclosure can be seen to be reflected in the idealist trace of what might be termed his 'impossible liberalism.' Thus, for instance, even if Derrida allows for no simple democratic and rational engagement of individuals, his politics remains inscribed within the $\mathrm{im} /$ possibilities of friendship: "O my friends, there is no friend" 31 - a politics committed to the infinite, but specific, openness to difference inscribed within the im/possible promise of liberal democracy; to the idea that its rational discursive interrogation of differences (appropriately complicated by deconstruction) is the locus of any possible justice-to-come. In a world in which liberal democracy has been shown to be all too complicit with and dependent upon a global capitalism of radical structural inequalities, Žižek can argue with some force that a politics centered upon the possibilities and impossibilities of the relation with the democratic other can scarcely be sufficient. Indeed, he can argue that its subtle foreclosure of difference (albeit in the name of openness to difference) belongs to a specific and delimited politics which, in its privileging of a 'liberal' paradigm, does crucial violence to wider possibilities of politics and justice. ${ }^{32}$

\section{Žižekian Self-Difference}

Žižek's appeal, in The Puppet and the Dwarf, to a Hegelian notion of the concrete self-difference of things is not only intended as an alternative to Derridean différance but as a self-criticism, relating to the very issues of violence raised by McQuillan. At this point in his work, Žižek recognizes the problematic nature of his own early conception of political act in terms of Lacan's notion, elaborated in his famous Seminar VII, of the Real as a quasi-

29 At the very least, "messianicity without messianism" cannot both respect the limits imposed by immanence and serve as a source of justification for deconstruction as such.

${ }^{30}$ Derrida's commitment to deconstruction is undoubtedly shaped by that concern.

31 Derrida, The Politics of Friendship, trans. by George Collins (New York and London: Verso 1997), 1.

32 Also instructive in this regard are the contributions of Derrida and Jürgen Habermas to Giovanna Borradori, Philosophy in a Time of Terror (Chicago and London: Chicago University Press, 2003). Something of the specificity, strengths, and limits of Derrida's politics are highlighted by their juxtaposition with those of Habermas, in their respective responses to the attacks of $9 / 11$, published in this work. 
Kantian transcendental 'Thing', beyond and prior to the Symbolic order of socio-political signification. ${ }^{33}$ Although The Sublime Object of Ideology, in which this conception of the Real was first elaborated, itself served as a productive specific, intervention which challenged prevailing 'postmodern' social and critical theory to embrace a new, unexpected post-Lacanian horizon of thought, the politics of the transcendental Real, as a theory, proved rather more problematic. Any act which would bear upon this Real could only be "tragic": either one ultimately succeeds in acting only within the Symbolic order, leaving the transcendental Real and its deep circumscription of socio-political possibilities unchanged (so that one's acts are always already futile from the outset), or one succeeds in acting upon the Real, but at the cost of a radical destruction of the existing social order, realized in a radical annihilation of the self (Lacan's passage à l'acte). ${ }^{34}$ Indeed, just two years earlier, Žižek had realized that Lacan's model of such an act, Antigone, is insufficient to the uncompromising violence of such an act. Her sacrifice of her place within the Symbolic order is only apparent, because her treasonous burial of her brother remains at the service of, and inscribes her existence within, a deeper law of the gods. In her stead, Žižek proposes the figure of Medea, whose murder of her children, means that there can be no recuperation of her act of vengeance against her husband. ${ }^{35}$ Faced with this disturbing logic, Žižek would soon come to the conclusion that the construction of the Real as transcendental Thing is not only flawed but, in fact, may be a key element of capitalist ideology, misdirecting political acts toward an impossible capitalism as phantom Thing (and thus toward an impossible act), and away from actually existing capitalism and its rather more mundane vulnerabilities to change. ${ }^{36}$

Instead, Žižek turned to an immanent conception of the Real as the internal limit of the Symbolic, such that the "not-All" of the Symbolic order, the encounter with its aporias and limits, is an encounter with the Real that exceeds, conditions, and precedes it. And this encounter with the SymbolicReal limit immanent to things is the encounter with their self-difference: with the excess of the thing over its signification, symbolized by the excess of the materiality of the letter over its signifying force. ${ }^{37}$ Act in turn is modeled on St. Paul's notion of overcoming the Sisyphean cycle of law, transgression and guilt via naive identification with elements of the law, attending to the SymbolicReal letter of the law, in order to expose and undermine the operation of its superego supplement, "the Law", which would grant it pure Symbolic

33 Jacques Lacan, The Ethics of Psychoanalysis: The Seminar of Jacques Lacan, Book VII, ed. by Jacques-Alain Miller, trans. by Dennis Porter (New York and London: Routledge Classics, 2008), 51ff; Slavoj Žižek. The Sublime Object of Ideology (New York and London: Verso, 1989), 16973.

$1,165-6$.

34 Slavoj Žižek and Glyn Daly, Conversations with Žižek (Cambridge: Polity, 2004), 150-

35 Slavoj Žižek, On Belief (New York and London: Verso, 2001), 158 n. 24.

36 Žižek and Daly, op. cit., 70

${ }^{37}$ Ibid., $59 \mathrm{ff}$. 
coherence. ${ }^{38}$ In Žižek's reading, Paul's act mirrors the later Lacan's notion of feminine subjectivation, in which woman identifies with elements of the Symbolic order, apart from the social-superego supplement that would constitute them as elements of a perfectly complete signifying system. By thus identifying with the Symbolic as a "not-All" traversed by multiple SymbolicReal limits, the feminine subject exposes and undermines the operation of these superego injunctions. ${ }^{39}$ The crucial point for the current discussion is that Žižek thus conceives of act as fundamentally within the Symbolic order, but without support from it: its significance does not depend upon the Symbolic order (and it can be justified only retrospectively in terms of the new situation it brings about). By contrast, masculine subjectivation involves identification with one's individual "little bit of the Real" left over from one's castrating insertion within the Symbolic order, such that a subjective act must both be entangled with and be destructive of that order. Arguably, this complex relation increases the vulnerability of the masculine subject to the subtle inversions of ideological interpellation. ${ }^{40}$ Thus, unlike Derridean messianicity (as Žižek conceives it), the Pauline-feminine act pays attention to the concrete self-difference of things, placing faith in the liberatory force of identification with a given element of the Symbolic order and its specific Symbolic-Real difference.

Two related issues arise for this account, however. First, if the Real is conceived as the internal limit of precisely a non-totalized, non-unified Symbolic order, a "not-All", then, what assurance is there that the Real so encountered is not of merely 'local' significance? Žižek's formulation cannot address the question of whether a universally significant act (and thus, for Žižek, a political act) remains possible if the notion of the not-All is taken seriously, that is, if there is only an assemblage of heterogeneous elements rather than a quasi-totality. Second, if the Real is only encountered immanently within the Symbolic order at its limits, what is there to suggest that there is a pre-Symbolic Real which exceeds the limited Symbolic structuring of being in our given society and corresponds with a fullness of being, which would support enhanced possibilities of human living? There might only be the Real as articulation of the dynamic, negative limit of the Symbolic order, and the prospect merely of substituting one deficient Symbolic order for another. This is the Žižekian equivalent of Derrida's question concerning whether there exists an ultimate possibility of justice that justifies deconstructive practices.

38 Žižek, The Puppet and the Dwarf, 67-9, 93ff. Such identification might involve taking literally the core democratic law about the equality of all, say, in favor of a marginalized ethnic group, refusing the supplementary social superego injunctions which typically circumscribe this equality and interpret it so as to 'square' it with all sorts of inequalities. This taking literally would, in turn, provoke reactions which render those supplementary injunctions visible and thus undermine their power.

${ }^{39} \mathrm{Ibid}$., 67.

40 An excellent elaboration of the ideological vulnerability of the masculine subject is provided in Jodi Dean, Žižeke's Politics (New York and London: Routledge, 2006), 1-46. 
Žižek's attempted solution to these problems has been two-fold. ${ }^{41}$ First, already beginning from The Puppet and the Dwarf, he begins to grant consistency to his notion of an unsupported act upon immanent Symbolic-Real self-difference in terms of the immanent movement of Hegelian dialectics ${ }^{42}$ Hegel, he argues, is the thinker par excellence of self-difference because the notion of dialectics involves the idea of a self-difference that "is no longer the contradiction between the undeconstructible pure Otherness and its failed actualizations/determinations, but the thoroughly immanent contradiction which precedes any Otherness." 43 Dialectics does justice to such difference by thematising its own failure to articulate this self-difference, pointing to, but not determining that difference in its specificity, via the self-rupturing movement of dialectics. Hence, the act of Pauline-feminine identification with the Symbolic-Real self-difference of elements of the Symbolic order can be thought of as a moment of a Hegelian dialectical movement. ${ }^{44}$ This process culminates in the Hegelian parallactic ontology of The Parallax View, where the Pauline-feminine act has been displaced by Bartleby's equally immanent "I would prefer not to" and this immanent act upon the Symbolic-Real limit is given a precise ontological significance and consistency. ${ }^{45}$ Second, aware that an immanently-conceived Hegelian dialectics is only politically significant if there is the possibility of a greater fullness of Being, which its ruptured syntheses bear upon, Žižek acknowledges in The Parallax View that one cannot know, from such an immanent vantage point, whether such a "pre-Symbolic X" exists. ${ }^{46}$ However, he argues that one must assume its existence as a kind of "methodological idealism" in order to support the possibility of a political act. ${ }^{47}$

It is not difficult to see that, with these solutions, Žižek ends up deploying precisely the kind of support for his arguments for which he criticizes Derrida. In the first instance, although Hegelian dialectics, as Žižek conceives it, does not determine the content of self-difference as such, it does define a minimal, negative quasi-formal condition of such self-difference:

41 The analysis that follows is all too schematic given the scope and complexity of Žižek's oeuvre. However, I hope that it is sufficient to highlight parallels with Derrida's approach to questions of difference and violence.

42 Note that Žižek's appeal to self-difference over Derrida abstract difference-to-come is thus, from the outset, not a simple return to concrete difference in-itself. Note also that $\check{Z}$ ižek takes Hegel's Absolute in his (Žižek's) usual non-metaphysical sense of a knowledge which is universal insofar as it repeatedly incorporates exceptional difference as a permanent rupture of its systematizations: a "bone in the throat." Žižek, The Puppet and the Dwarf., 66, 130-1, 139-141.

43 Ibid., 140.

44 It is not insignificant that he has suggested that, in his recent work, he has shifted from a Lacanian reading of Hegel, to a Hegelian reading (and contextualization) of Lacan. Žižek, "Slavoj Žižek: Interview (with Sean O'Hagan,)", The Observer, <http://www.guardian.co.uk/culture/2010/jun/27/ slavoj-zizek-living-end-times>, 27 June 2010 . 2006), 381-5

45 Slavoj Žižek, The Parallax View (Cambridge, Massachusetts, and London: MIT Press,

46 This is the political price of Žižek's move from Lacan's earlier transcendental conception of the Real to his later immanent one.

47 Ibid., 390 n.21. 


\section{FINITUDE AND VIOLENCE}

decisive difference is that self-difference which can be inscribed within Hegelian dialectics - within its always already 'failed' discourse and concomitantly precise economy of disruption and disrupted synthesis. That is to say, if Žižek does not define the content of self-difference as such, he places a positive stricture upon it by defining in advance its relation to other instances of self-difference, inscribing its form minimally but positively. In Meillassoux's terms, Žižek posits a principle which conditions all difference, beyond specific instances in which that principle might be thought. That this quasi-formal condition involves a limiting of difference can be briefly illustrated in relation to The Parallax View. As commentators such as Simon Critchley have argued, Bartleby's "I would prefer not to" scarcely realizes Žižek's characteristic concern with a decisive, universally significant political act. 48 Žižek's very effort to articulate the consistency and specific significance of the act tends to circumscribe its force. This is because to specify the significance of difference is already to relate it to 'the Same', and to circumscribe what Gilles Deleuze would term its "pure difference." Bartleby's peculiar negation might give no oxygen to the ideological notion of the Symbolic order as unified "big Other", but Žižek's formalization delimits the relation of difference to the Symbolic order of that negation, precisely as Derrida's generalization of deconstruction turns its specific force into a limit upon difference.

Indeed, shortly after this work, Žižek turns to the Benjaminian notion of a "divine violence", attempting to isolate the possibility of a pure violence of act which is neither that of a transcendent divine being, nor a tragic-suicidal passage à l'acte, nor again of statist sovereign violence nor that of anarchism. That is, he explicit wants to juxtapose and identify divine violence with what is conceived once more as the unsupported act "made in absolute solitude, with no cover in the big Other." 49 The difficulty with this move is that, if it rescues the immanent political act from the circumscriptions of the ontology of The Parallax View, it requires the identification of the immanent act in faith with an act of pure violence capable of transcending the problematic violences with which the world is all too familiar. The immanent act of faith, however, as immanent, is inevitably blind both concerning its universal significance and concerning whether its potential effectiveness for change is supported by the existence the greater fullness of being of the pre-Symbolic Real. Hence, the 'simple' naive faith of identification with elements of the Symbolic as "not All" problematically gives way to a more substantial and split act of faith: faith that this unsupported act is a universally significant act; faith that such an immanent act can constitute a pure, world-changing violence. The structure of this claim is precisely that which he diagnoses in Derrida's thinking concerning justice: Žižek acts in the hope that an immanent act upon/of self-difference can constitute an act of decisive political change leading to enhanced possibilities of human living. Insofar as he persists in this hope, without evidence to support it

48 Simon Critchley, "Foreword: Why Žižek Must Be Defended," in Paul Bowman and Richard Stamp, eds., The Truth of Žižęe (London and New York: Continuum, 2007), xiv-xvi.

${ }^{49}$ Slavoj Žižek, Violence: Six Sideways Reflections (London: Profile Books, 2008), 170-1. 
(and as shall be seen such an act has proven always to come for $\check{Z}$ ižek), this claim becomes in practice, an ontotheological claim which privileges certain forms of difference.

Moreover, at this point, Žižek's thought would appear to be vulnerable to McQuillan's criticisms. He allows for no framework, criteria or limits which would qualify the decisive political act. In view of Žižek's immanent framework of thought, an act could be adjudged decisive for change by its success, and, then, by definition, only from the perspective of the new situation which that act had succeeding in bringing about. Žižek, however, is too rigorous a political thinker to allow such an identification of immanent act and divine violence to be made too readily in practice. Hence, although he identifies historical acts that have constituted acts of divine violence, ${ }^{50}$ he has not identified any contemporarily occurring act or event as fulfilling these conditions. Instead, in a further mirroring of Derrida, divine violence remains a possibility that is always in practice to come. No less than in the case of Derrida, this is not simply a matter, for Žižek, of deferral of action but of an ethos governed by Samuel Beckett's injunction to "Try again. Fail again. Fail better." 51 The pure act of violence 'to come' becomes a means of critiquing actual acts in the present, ethically pushing them toward greater purity without ever allowing for simple valorizations of actions. As in relation to justice-tocome, divine violence 'to come' serves as an impossible horizon of act, which even if it cannot be attained, both locates acts within an absolutely demanding ethical horizon and underscores the responsibility to act in spite of impossibility.

It is in this context that Žižek's appeal to Robespierre's terror ought to be read. Žižek is primarily concerned to provoke us into thinking about political acts beyond our usual, often ideologically-limited, horizons of thought. Against postmodern equivocations and poststructuralist appeals to impossibility, he is determined to confront us with possibilities of political action which no longer seem possible or desirable to us, and, indeed, may no longer be possible or desirable. However, by confronting us with radically 'other' possibilities (and even as he confronts us with the vista of a violent politics, he does not suggest that we naively adopt Robespierre's viewpoint), 52 he seeks to refuse any presuppositions about politics which might become a limiting transcendental condition of political possibility. As much as anything, in this analysis, Žižek confronts us with the specificity and limits of a politics which would minimize violence, by positing its 'Other'. By pushing thought repeatedly into other spaces, he goes beyond the limit of Derrida's messianicity, which even if it supposes "no differance without alterity, no alterity without singularity" tends to circumscribe alterity and singularity within the logic and economy of the future-to-come. ${ }^{53} \mathrm{Or}$, at least, he does so with respect to

50 Ibid.

51 Slavoj Žižek, In Defense of Lost Causes (New York and London: Verso, 2008), 210.

52 Žižek, "Robespierre, or, The 'Divine Violence' of Terror,” ix.

53 Derrida, Specters of Marx, 31. Žižek calls for a Derridean recognition of the violence of deconstruction: the violence necessary to make visible that "supreme" socio-symbolic 
Derrida's thought and, more broadly, postmodern discourse. No less than Derrida, his own efforts in offering a general description of political act as such retains, as has been seen, an ontotheological trace and a corresponding, problematic privileging of what in itself is ambiguous difference. As such, although he performs a different mode of openness to difference, finally, Žižek ends up repeating a form of that which he finds problematic in Derrida's work.

\section{Conclusion: The Problem of Finitude}

The preceding analysis suggests that Žižek's work, no less than Derrida's, runs up against a 'problem of finitude,' that is, the problem of constructing a consistently immanent (political) discourse within and respecting the limits of a finite horizon of thought. Each seeks to delimit the kinds of act that attend to the self-difference of things so as to remain open to the possibility of justice (Derrida)/decisive political change (Žižek). In so doing, however, each, as it were, short-circuits the ambiguities of finite difference, delineating negatively and formally a privileged locus of justice/change, supported by minimal but decisive ontotheological assumptions. Derrida appeals to a 'faith', not simply in the possibility of justice, but in the decisive significance for the content of experience of a certain structure of experience, which allows one to privilege openness to an otherwise radically ambiguous future - a future open to 'the worst' no less than the possibility of justice. Žižek, in turn, appeals to 'faith' that the unsupported act of a certain Hegelian self-difference has both universal significance and signifies decisive change, even if by definition an unsupported act of ambiguous significance within a finite world. If Derrida is concerned to minimize violence, the price of his ontotheological appeal is action in the present that must exclude difference that cannot be incorporated within his structure of openness to the future-to-come; if Žižek seeks to purify violence, the price is an apparently infinite deferral of act (the "big Act" is always to come) as he awaits the miraculous occurrence of the immanent act which will have proven to be an act of such pure divine violence. The price for politics is, thus, either an excessively narrowly delimited political act (Derrida) or an excessively fetishized and deferred political act (Žižek).

The contours of this shared problem of finitude suggests a return to Žižek's call for a deconstruction of deconstruction capable of fundamentally specifying, delimiting and rupturing deconstruction, not so as to discredit it, but to clarify its specificity of object, scope, and force, thus contextualizing it and making room for 'other' difference and other forms of politics. Equally suggested is a stronger form of Žižek's Beckettian ethics of failure which

violence that is "no longer experienced as violence, since it determines the 'specific colour' of the very horizon within which something is perceived as violence." Slavoj Žižek, The Metastases of Enjoyment: Six Essays On Woman and Causality (New York and London: Verso, 1995), 204) However, he considers Derridean deconstruction to remain contaminated by that which it would contest, and so it fails to attain to 'divine violence' or to fully grasp the latter's economy and logic. 
would be capable not merely of preparing to 'fail again, fail better' (and thus tracing a locus ever impossibly-distant from its asymptotic goal), but of recognizing successful change, however, partial and ambiguous, in such failure - in the absence of a "big Act". That is to say, if politics in a finite world cannot (and ought not) avoid determinate articulations such as those found in the work of Derrida and Žižek, there is a need to locate determinate formulations of political act as moment of a finite practice, which resists the raising of strategic privileging of certain forms of difference, in particular contexts, to the level of general ontology - a move which attempts to circumscribe the ambiguities of finite difference that is unconditioned by any ontotheological finality. As such, for instance, the "big Act" becomes a purely political imperative, a kind of heuristic within which to think and remain committed to political act in its (desired) maximal realization as radical change. Here, however, the recognition of change in (partial) 'failure' would constitute a refusal to fetishize "big Act" as some impossible "Thing'/horizon of a subsequently static world. In other words, in the case of both Derrida and Žižek, it is a matter of restoring to the notions of justice-to-come/big-Act-tocome the status of practical efforts to theorize immanently in order to act immanently - practical efforts which must be renewed, recommenced and become 'other', as acts induce significant (if not decisive) change and, at least partially, 'other' unanticipated contexts and differences are encountered. Unless ontotheological privilege is stripped from these notions, in the place of a justice-to-come or radical political transformation, the very efforts at justice or transformation will inadvertently be the source of a certain violence of the Same.

Independent Researcher, Cork, Ireland

\section{References}

Borradori, Giovanna, Philosophy in a Time of Terror: Dialogues with Jürgen Habermas and Jacques Derrida (Chicago and London: University of Chicago Press, 2003).

Critchley, Simon, "Foreword: Why Žižek Must Be Defended," in The Truth of Žž̌ek, ed. by Paul Bowman and Richard Stamp (London and New York: Continuum, 2007), xi-xvi..

Dean, Jodi, Žižek's Politics (New York and London: Routledge 2006).

Derrida, Jacques, "Différance," in Margins of Philosophy, trans. by Alan Bass. (Harvester Press: Brighton, 1982), 1-27.

Specters of Marx: The State of the Debt, the Work of Mourning, and the New International, trans. by Peggy Kamuf (New York and London: Routledge, 1994). , The Politics of Friendship, trans. by George Collins (New York and London: Verso, 1997).

"Faith and Knowledge: The Two Sources of 'Religion' at the Limits of Reason Alone," in Religion, ed. by Jacques Derrida and 
Gianni Vattimo, trans. by David Webb (Cambridge: Polity Press, 1998), 1-78.

"For a Justice to Come: Interview with Jacques Derrida (by Lieven de Cauter, 2004)," in The Derrida-Habermas Reader, ed. by Lasse Thomassen (Edinburgh: Edinburgh University Press, 2006), 259-269.

Foucault, Michel, The Archaeology of Knowledge, trans. by Alan Sheridan Smith (London: Routledge, 1972).

Foucault, Michel, and Chomsky, Noam, "Human Nature: Justice vs. Power (1971): A Debate between Noam Chomsky and Michel Foucault," in The Chomsky-Foucault Debate: On Human Nature (New York: New Press, 2006), 1-67.

Lacan, Jacques, The Ethics of Psychoanalysis: The Seminar of Jacques Lacan, Book VII, ed. by Jacques-Alain Miller, trans. by Dennis Porter (New York and London: Routledge Classics, 2008).

McQuillan, Martin, "Extra time and the death penalties: on a newly arisen violent tone in philosophy," in Derrida Today, 2:2 (2009), 133-150.

Meillassoux, Quentin, After Finitude: An Essay on the Necessity of Contingency, trans. by Ray Brassier (London and New York: Continuum, 2008).

Žižek, Slavoj, The Sublime Object of Ideology (New York and London: Verso, 1989).

, The Metastases of Enjoyment: Six Essays On Woman and Causality (New York and London: Verso, 1995).

The Puppet and the Dwarf: The Perverse Core of Christianity (Cambridge, Massachusetts, and London: MIT Press, 2003). , On Belief (New York and London: Verso, 2001).

"The Real of Sexual Difference," in Interrogating the Real, ed. by Rex Butler and Scott Stephens (New York and London: Continuum, 2005), 304-27.

, The Parallax View (Cambridge, Massachusetts, and London: MIT Press, 2006).

, 'Introduction: Robespierre, or, The 'Divine Violence' of Terror", in Robespiere, Maximilien, Virtue and Terror, ed. by Jean Ducange, trans. by John Howe (New York and Lonodn: Verso, 2007), vii-xxxix.

, Violence: Six Sideways Reflections (London: Profile Books, 2008).

In Defence of Lost Causes (New York and London: Verso, 2008).

"Slavoj Žižek: Interview (with Sean O'Hagan,)", in The Observer, <http://www.guardian.co.uk/culture/2010/jun/27/slavoj-zizekliving-end-times>, 27 June 2010.

, “Lenin's Full Subjective Engagement," www.lacan.com, < http://www.lacan.com/thesymptom/?page id=1012>, 19 August 2011.

Žižek, Slavoj, and Daly, Glyn, Conversations with Žižcek (Cambridge: Polity, 2004). 